\title{
Słowo od autorów
}

Zamieszczone tu teksty są rezultatem inspiracji nowymi poszukiwaniami, ideami, perspektywami pojawiającymi się we współczesnej humanistyce, które odrzucają, renegocjują oraz podają pod refleksję tradycyjny i dominujący w niej antropocentryzm. Poszukujemy innego sposobu konceptualizacji, opisu i wyjaśniania relacji zachodzących między nami — ludźmi — a innymi istotami i zjawiskami świata, w którym żyjemy. Takiego, w którym człowiek nie jest miarą wszechrzeczy, lecz próbuje zrozumieć otaczającą go Inność czy Inności, a także swoją odmienność względem nich. Poszukuje dodatkowo odpowiedniej drogi poznania, ale też samych form przedstawieniowych, aby zrozumieć te relacje i odnaleźć w nich własne miejsce. Przedstawione tu prace to efekty nadal trwających poszukiwań, które domagają się kontynuacji. Nasze teksty różni nie tylko tematyka. Są również przykładem, jak różną postać mogą przyjąć inspiracje interesującymi nas ideami. W wielu wypadkach odwołujemy się też do starych tekstów, pomysłów, badań, które naszym zdaniem we współczesnym kontekście teoretycznym uzyskują nowe znaczenie.

Dialog $\mathrm{z}$ antropocentryzmem, przypatrywanie się mu, próby jego zastąpienia to także refleksja nad relacjami władzy i wysiłek, by je przeformułować, by wyobrazić sobie świat, człowieka, zwierzę, roślinę, kamień na nowo. Wyobrazić sobie świat inaczej to przecież również pracować $\mathrm{z}$ wyobrażeniami dobrze zakorzenionymi w antropocentrycznej kulturze: czy są w nich pęknięcia, przemilczenia, niedopowiedzenia, z których możemy snuć nowe wątki? Czy możemy im stawiać pytania i wyzwania, dzięki którym teksty zaczną żyć poza utartymi ścieżkami interpretacyjnymi? Gdzie zaprowadzi nas zderzanie tradycyjnych ujęć z próbami ich przekroczenia, podważenia, obejścia?

Refleksja nad antropocentryzmem to też namysł nad tym, w jaki sposób on funkcjonuje, jaką koncepcję człowieka $\mathrm{i}$ innych istot promuje, jakie relacje $\mathrm{z}$ innymi są w zasięgu jego wyobrażeń, a jakie wydają się zakazane, niemożliwe, patologiczne, chore, nie do pomyślenia. A zatem chcąc myśleć poza antropocentrycznym paradygmatem, myślimy jednocześnie na nowo o człowieku, inności, tożsamości — czym byłyby, czym mogłyby być w sytuacji, w której przestaje być głównym punktem odniesienia? Jak zmienia to jednostki, relacje między nimi, przynależność gatunkową, hierarchie oraz struktury władzy i dominacji? Co nowego się pojawia? Co znika? Co nabiera nowych znaczeń? Co staje się możliwe do pomyślenia, a co się wymyka lub co sami wykluczamy? Czy faktycznie żyje- 
my w epoce antropocenu, czy też są to diagnozy stawiane na wyrost, które może zweryfikować zmiana postawy wobec istot innych niż ludzie?

Tego rodzaju refleksja zawsze wiąże się z przyjęciem paradygmatu posthumanistycznego, wynikającego z gruntownych rozważań nad humanizmem, aczkolwiek w proponowanych tekstach rozwija się w różne ujęcia - związane z kondycją środowiska, inspirowane studiami nad zwierzętami i roślinami, teorią aktora-sieci i wreszcie — odkryciami współczesnej fizyki.

Elementem natury jest woda. Bez niej nie ma życia. W przypadku starożytnego Egiptu - kraju, w którym bardzo szybko wykształciła się cywilizacja Nil odgrywał tak ważną rolę, iż stał się głównym czynnikiem jej rozwoju. Jego wpływ na życie Egipcjan był tak istotny, że uznano go za boga. Karmił, poił, nawoził pola, wyznaczał rytm życia pokoleń; dał im wszystko, czego potrzebowali, łącznie z uporządkowaniem świata i społeczeństwa. Religia, sztuka, obyczajowość, rozrywki wiązały się z Nilem. Dziś wielu myśli, że to my ujarzmiamy rzeki, wodę, naturę. A może warto zapytać, czy obecnie nasza cywilizacja nie jest podobnie ujarzmiona przez te żywioły, jak kiedyś ta w Egipcie? Czy nasze życie, dobrobyt, szczęście naprawdę już od nich nie zależą?

Interesująca pozostaje także sfera relacji między człowiekiem a maszynami, robotami. Choć pozbawione są one autonomicznej woli czy podmiotowości i zostały powołane do życia przez człowieka w celu spełniania konkretnych funkcji, nie można odmówić im sprawczości w zakresie wywierania wpływu na kształt i zasady obowiązujące w „człowieczym” świecie. Robotyczna, nieorganiczna Inność staje się coraz bardziej wyraźna, a naszą powinnością jest zwrócenie na nią uwagi, podjęcie próby zrozumienia jej specyfiki. A zwierzęta? Jaka relacja zachodzi między nami a nimi, poza tą, że my także jesteśmy zwierzętami? Czy to myśmy oswoili psy, czy może to one oswoiły nas i nadal to czynią? A może mamy do czynienia ze wzajemnym oswajaniem, porozumiewaniem? Temat podjęty kilka lat temu przez Donnę Haraway w jej słynnych manifestach — cyborgów i gatunków stowarzyszonych - wciąż pozostaje aktualny i domaga się kolejnych odczytań.

A co z przedmiotami? Nieustannie otaczamy się przecież nowymi rzeczami. Gadżety elektroniczne dominują w ludzkich relacjach. Uwikłanie w przedmioty to jeden z kulturowych wyróżników ludzkich cywilizacji. Te uwikłania studiują archeolodzy i historycy teatru. W końcu bez maski nie mogłaby się narodzić antyczna tragedia czy komedia. Kulturoznawcy i filozofowie od dawna badają afordancje rzeczy, a ostatnio coraz częściej także ich sprawczość - często, ale niewyłącznie powiązaną z ludzką intencyjnością (jak udowadniają teoretycy z kręgu object oriented philosophy). Czy przedmiot może inicjować wydarzenia kulturowe? W jaki sposób poszerza ludzki umysł? Modyfikowanie ciała protezami prowadzi wszak nie tylko do zmian biologicznych, lecz także inicjuje przemiany kulturowe. Uwikłani w rzeczy tracimy podmiotowość. Istnieją jednak i takie koncepcje, które zakładają, że nie mamy do czynienia z utratą, ale ze znaczącą modyfikacją — jak w interesu- 
jącej propozycji „sojuszu transwersalnego” jednej z najbardziej znanych badaczek posthumanizmu - Rosi Braidotti. Sojusz tego rodzaju oznacza próbę afirmacyjnej konceptualizacji współistnienia istot żywych i maszyn, które często dzielą wspólny los, tworząc nowe rodzaje tożsamości — okołocyborgiczne, hybrydyczne. Być może warto rozważyć nowe definicje człowieka, które na polu filozofii, ale też biotechnologii pojawiają się w ostatnich latach dość często. Przykład może stanowić koncepcja Susan Squier dotycząca „tożsamości przejściowych” (liminal indentity), która obejmuje wiele bytów jeszcze nie do końca ukształtowanych, czy przekształcanych technologicznie, znajdujących się niejednokrotnie na granicy między tym, co żywe i martwe, organiczne i nieorganiczne. Genetyka coraz częściej dopełniana jest dynamicznymi i mniej stabilnymi modelami epigenetycznymi.

Od 2017 roku znamy już ponad 3500 planet pozasłonecznych. Kolejnych 4500 to tak zwane kandydatki, które oczekują na potwierdzenie. Wśród nich są również planety skaliste, rozmiarami i masą podobne do Ziemi. Dlatego też pytanie: „czy zobaczymy kiedyś drugą Ziemię?” przestaje być aktualne. Coraz częściej zastanawiamy się: „kiedy zobaczymy drugą Ziemię?”. Jesteśmy coraz bardziej pewni, że planet podobnych do naszej, na których panują warunki odpowiednie do rozwoju życia, jest całe mnóstwo. Globalna, w skali Wszechświata, powszechność planet z życiem oznaczać będzie, że nasza wiara w wyjątkowość człowieka zostanie zamknięta do lokalności o rozmiarach Układu Słonecznego. Z perspektywy takich odkryć coraz częściej dochodzimy do wniosku, że nie znajdujemy się w wyjątkowym miejscu Wszechświata, w niepowtarzalnym układzie planetarnym, na planecie jedynej w swoim rodzaju. Jesteśmy zlepkiem atomów, które są powszechne w globalnej skali całego Wszechświata i w każdej jego lokalności mogły utworzyć podobny organizm. Wodór, który powstał w Wielkim Wybuchu, węgiel wytworzony w trakcie ewolucji gwiazd o małych masach, tlen powstający w tych bardziej masywnych... Zaczynamy rozumieć, że nasza lokalność nie jest we Wszechświecie wyjątkowa. Jest jedną z niezliczonych lokalności tworzących globalność całego Wszechświata. A może on także jest tylko jednym z nieskończonej liczby innych wszechświatów? Warte uwagi są w tym kontekście również próby badania tej ziemskiej „lokalności”, rozważania nad siłami fizycznymi, dominującymi i na Ziemi, i w Kosmosie, które determinują codzienne życie istot żywych, choć te ostatnie często nie są tego świadome. Doskonały przykład stanowią różne rodzaje promieniowania (słoneczne, radioaktywne, jonizujące etc.), które oddziałują na biologiczne organizmy, kształtują je i modyfikują. Czynniki działające lokalnie i „oblepiające” żywe istoty Timothy Morton nazywa „hiperobiektami”, sugerując, że nie pełnią one funkcji tradycyjnych przedmiotów, używanych wyłącznie przez ludzi, ale stanowią siły, które transponują ich ontologię; kształtują związki, które opierają się utrwalonym konceptualizacjom, podając w wątpliwość sensowność paradygmatu antropocentrycznego. 